\title{
KAJIAN ETHYLENE TRIPLE RESPONSE TERHADAP KECAMBAH TIGA VARIETAS KACANG HIJAU
}

\author{
Kristiani Walesasi ${ }^{1)}$, Feky R. Mantiri ${ }^{\left.{ }^{*}\right)}$, Herny Simbala ${ }^{1)}$, Marhaenus Rumondor ${ }^{1)}$ \\ ${ }^{1)}$ Program Studi Biologi FMIPA Universitas Sam Ratulangi \\ Jl. Kampus Unsrat, Manado 95115 \\ ${ }^{*}$ Coresponding Author: fmantiri@yahoo.com \\ freanevol08@gmail.com; hsimbala@yahoo.co.id; marhaenusrumondor@yahoo.com
}

\begin{abstract}
ABSTRAK
Pembudidayaan tanaman kacang hijau selalu terkendala dengan keadaan lahan yang terbatas. Tanaman kacang hijau di tanam dengan tumpang sari, sehingga mengakibatkan tanaman ini tumbuh dengan keadaan ternaungi. Naungan ini menyebabkan naiknya produksi etilen, sehingga menimbulkan triple response yang dapat mempengaruhi pertumbuhan dan perkembangan tanaman. Oleh karena itu hal ini menjadi alasan dilakukan penelitian ini dengan etilen pada tiga varietas kacang hijau yaitu VIMA I, Seriti dan Kutilang. Setelah dikecambahkan tujuan untuk menyeleksi varietas kacang hijau yang tahan dengan adanya peningkatan jumlah selama 5 hari, panjang kacang hijau varietas VIMA I yang diberi karbid (penghasil etilen) adalah yang tertinggi. Bengkokan varietas kacang hijau yang terendah adalah varietas VIMA I. Namun untuk diameter kecambah ketiga varietas tidak berbeda nilainya baik yang diberi karbid maupun yang tidak diberi karbid. Dari penelitian ini menunjukkan varietas VIMA I adalah tanaman yang tahan terhadap peningkatan etilen, sehingga varietas ini berpotensi untuk ditanam di naungan.
\end{abstract}

Kata Kunci :Etilen, Triple Response, Kacang Hijau

\section{STUDY OF ETHYLENE TRIPLE RESPONSE ON SEEDLINGS OF THREE VARIETIES OF MUNGBEAN}

\begin{abstract}
Grow green beans are always constrained by the state of limited land. Thus the green bean crop planted with intercropping, resulting in these plants grow with shady circumstances. However, this shade causes increased production of ethylene, causing triple response which can affect plant growth and development. Therefore this is the reason of this research with the aim of selecting resistant varieties of green beans with the increased amount of ethylene on three varieties of green beans that VIMA I, Seriti and Kutilang. Once germinated for 5 days, the length of green beans varieties by VIMA I carbide (ethylene producer) is the highest. And bend varieties of green beans were the lowest observed varieties VIMA is I who have given carbide. But for the three varieties of sprouts diameter does not vary in value whether it is given or not given acetylene carbide. From this research shows VIMA I is a plant varieties that are resistant to an increase in ethylene, so that this variety has the potential to be planted in the shade.
\end{abstract}

Keywords: Ethylene, Triple Response, Mung Bean

\section{PENDAHULUAN}

Tanaman kacang hijau (Vigna radiata $L$. Wilzcek) termasuk suku polongpolongan Fabaceaeyang memiliki manfaat sebagai sumber bahan pangan berprotein nabati tinggi, yang dapat digunakan dalam berbagai macam produk dan jenis makanan, dan merupakan salah satu komuditas pangan yang menjadi sumber energi pengganti selain kacang kedelai. Kacang hijau merupakan tanaman jenis Leguminoceae yang tahan akan kekeringan, sehingga mempunyai potensi besar untuk dikembangkan. Kacang hijau merupakan salah satu komoditas kacang-kacangan yang banyak dimakan rakyat Indonesia.Secara agronomis dan ekonomis, tanaman kacang hijau memiliki kelebihan dibanding tanaman kacangkacangan lainnya (Mustakim, 2015). 
Lingkungan, iklim, cuaca, kondisi tanah, curah hujan serta kelembaban, sangat berpengaruh besar pada perkecambahan kacang hijau. Hal ini menjadikan kacang hijau menjadi tanaman yang tahan akan kekeringan, jarang diserang hama dan penyakit dapat dipanen pada umur 55-60 hari, dan dapat tumbuh di tanah yang kurang subur, sehingga membuat kacang hijau mudah untuk dibudidayakan (Sunantara, 2000).

Pertumbuhan adalah proses fisiologis yang ditandai dengan bertambahnya jumlah sel dan bertambahnya volume sel yang bersifat irreversible (tidak dapat mengecil kembali). Kacang hijaumerupakan tanaman yang tumbuh di daerah tropis, ketinggian tanah yang cocok untuk tanaman ini yaitu $500 \mathrm{~m} \mathrm{dpl}$. Suhu yang dibutuhkan untuk budidaya kacang hijau adalah suhu yang panas, karena pada musim hujan pertumbuhan vegetatif sangat cepat, sehingga mudah rebah. Tanah yang cocok untuk budidaya kacang hijau adalah yang memiliki $\mathrm{pH}$ 5,8. Jika $\mathrm{pH}$ kurang dari 5, tanah sebaiknya diberi kapur terlebih dahulu dengan waktu 2-4 minggu sebelum penanaman (Mustakim, 2015).Semua varietas kacang hijau cocok ditanam di lahan sawah atau lahan kering. Tanaman kacang hijau sangat bergantung pada besar kecilnya volume pencahayaan ketika berada dalam fase perkecambahan, karena rentan dengan kelebihan dan kekurangan hormon etilen, sehingga dibutuhkan varietas yang dapat beradaptasi terhadap lingkungan tersebut.

Tanaman kacang hijau adalah tipe tanaman yang dapat ditumpangsarikan dengan tanaman lainnya, misalnya jagung, ubi kayu maupun tanaman perkebunan lainnya, terutama tanaman yang masih muda. Lahan perkebunan dapat dimanfaatkan sebagai tanaman pangan, paling tidak untuk tiga tahun pertama, namun masalah yang selalu dihadapi dalam sistem tumpang sari adalah adanya perebutan unsur hara air, dan cahaya. Hasil penelitian pada sistem tumpang sari tanaman pohon dan kacang hijau, jagung dan pechai menunjukkan bahwa kacang hijau mempunyai adaptasi lebih baik terhadap naungan dibandingkan dengan jagung dan pechai (Katayama et al., 1998).

Penelitian Mejaya (1989) yang menunjukan adanya penurunan hasil kacang hijau pada tumpang sari jagung dan kacang hijau sangat beragam, dengan kisaran antara 1-44 \%. Menurut Sangakkara (1988) persaingan cahaya merupakan salah satu faktor penyebab tingginya penurunan hasil kacang hijau pada sistem tumpang sari. Upaya yang dilakukan untuk mengisi peluang tersebut di atas adalah dengan mencari atau mengembangkan varietas kacang hijau yang toleran terhadap penaungan.

Penelitian tentang kajian Ethylene Triple Response juaga pernah dilakukan oleh Wardani (2014), namun dengan objek yang berbeda yaitu menggunakan kacang kedelai yang dimana membuktikan bahwa setiap varietas yang tahan terhadap peningkatan jumlah etilen memiliki karakteristik dengan nilai panjang kecambah yang tinggi namun derajat bengkokan yang paling rendah.

Persaingan cahaya merupakan salah satu faktor penyebab tingginya penurunan hasil kacang hijau pada sistem tumpang sari. Penggunaan genotipe toleran merupakan salah satu cara untuk memperkecil kehilangan hasil. Berdasarkan penelitian yang dilakukan di Kebun Percobaan Balitkabi, Malang pada bulan Februari hingga Mei 2002. Lima genotipe kacang hijau (VC2768B, Kenari, Nuri, Lokal Wongsorejo dan MLG 431) diuji pada empat tingkat penaungan $(0,25,50$, dan $75 \%)$ dan hasil penelitian menunjukkan bahwa hasil kacang hijau pada penaungan $75 \%$ lebih rendah dari penaungan $50 \%$ dan 255 , masing-masing $34,01 \%$ dan $65,21 \%$. Hasil rata-rata, rata-rata geometrik dan indeks toleransi terhadap cekaman merupakan tolak ukur yang baik untuk memilih genotipe kacang hijau berpotensi tinggi dan toleran terhadap penaungan. Genotipe VC2768B, Kenari dan Lokal Wonsorejo toleran terhadap penaungan hingga $75 \%$ (Mustakim. M.. 2015)

Etilen merupakan hormon tumbuhan (fitohormon) berwujud gas yang biasanya diproduksi olehtanaman dalam jumlah tertentu. Dengan adanya faktor cekaman lingkungan seperti naungan, kekeringan, kebanjiran, tekanan mekanis, pelukaan serta infeksi memicu tanaman untuk memproduksi etilen secara berlebihan yang menghambat pertumbuhan tanaman. Etilen ditemukan pada tahun 1800-an ketika gas batu bara digunakan sebagai bahan bakar untuk lampu jalan. kebocoran pipa - pipa gas 
menyebabkan pohon-pohon disekitarnya mengugurkan daun sebelum waktunya, sehingga pada tahun 1879 seorang ahli fisiologi terkenal dari Rusia Dimitry Neljubow menyatakan bahwa gas etilen dapat mempengaruhi pertumbuhan tanaman. Kemudian pada tahun 1901-1926 Dimitry Neljubow mendemonstrasikan gas etilen yang merupakan faktor aktif dalam gas batu bara dan menunjukkan bahwa etilen menyebabkan respon rangkap tiga atau triple response pada kecambah kacang kapri. Triple response yang dimaksud antara lain menghambat pemanjangan batang, menebalkan batang dan munculnya kebiasaan membuat lekukan (hook) yang menyebabkan batang tumbuh secara horizontal atau mendatar (Salisbury dan Ross, 1995).

Penelitian tentang Triple Response terhadap tanaman banyak dilakukan seperti penelitian dari Steward, Liebarman dan Kunishi (1974) yang menunjukkan terjadinya pemelaran sel kearah samping pada kecambah kacang kapri dan penelitian pada mutan-mutan Arabidopsis, antara lain ein ialah mutan yang tidak memperlihakan triple response setelah diberi etilen dan ctr, yaitu mutan yang memperlihatkan triple response meskipun tidak ada etilen. Studi molekuler yang dilakukan oleh Blecker et al., (1988) terhadap mutan Arabidopsis yaitu mutan etr tidak menunjukkan respon terhadap etilen. Guzman dan Ecker (1990) juga melaporkan adanya mutan yang sensitif terhadap etilen, yaitu ein2 dan ein1, serta etol-1 yang menunjukkan triple response tanpa diberi etilen. Selain itu sejauh ini di Indonesia penelitian tentang ethylene triple response pada tanaman selain kapri, Arabidopsisdan kacang kedelaibelum pernah di lakukan. Berdasarkan gagasan pokok di atas perlu dipelajari dan diseleksi varietas kacang hijau yang tahan akan peningkatan etilen.

\section{METODE PENELITIAN}

Penelitian inidilaksanakan pada bulan 27 Juni - 4 Juli 2016 selama 1 minggu. Kegiatan penelitian ini dilakukan di Laboratorium Ekologi dan Biokonservasi FMIPA Universitas Sam Ratulangi, Manado, Sulawesi Utara.

Alat yang digunakan pada penelitian ini adalah, mikroskop, oven, kaca benda, kaca penutup, timbangan, jangka sorong, penggaris, busur derajat, botol air mineral $600 \mathrm{ml}$, kardus, selotip, gelas ukur, alat tulis menulis dan kamera. Bahan yang digunakan ialah, 3 varietas benih kacang hijau (VIMA I, Sriti dan Kutilang), karbid, plastik, larutan pemutih komersial dan akuades. Media tanam pada penelitian ini adalah kertas merang.Alat dan bahan serta kegunaannya dapat dilihat pada tabel berikut.

Penelitian ini di rancang dengan menggunakan Rancangan Acak Lengkap (RAL) faktorial berupa 2 faktor, yaitu faktor varietas (3 varietas) dan faktor ada tidaknya karbid.

Tahap persiapan meliputi pemilihan benih kacang hijau yang berkualitas, sterilisasi benih dan media, pelapisan media dengan plastik, persiapan wadah perkecambahan dan pembuatan gas etilen. Pemilihan benih kacang hijau dilakukan dengan

merendam dalam air selama satu jam. Hal ini dilakukan untuk menentukan kualitas benih dengan ketentuan benih yang tenggelam adalah benihyang baik dan digunakan. Kemudian benih disterilisasi dengan menggunakan larutan pemutih komersial 2\% selama 5 menit dan dibilas dengan akuades sebanyak 3 kali (Nioet al., 2010). Sterilisasi media, yaitu 90 lembar kertas merang berukuran $30 \mathrm{~cm} \times 20 \mathrm{~cm}$, dengan memakai oven selama 24 jam pada suhu $70^{\circ} \mathrm{C}$ (Satriadi, 2009).

Selanjutnya kertas merang dilapisi dengan plastik yang dipotongberdasarkan jumlah dan ukuran kertas merang dengan tujuan agar kertas merang tetap lembab. Wadah yang digunakan adalah 30 botol air mineral $600 \mathrm{ml}$ yang dipotong bagian atasnya. Kemudian disiapkan 2 buah kardus berukuran $24 \times 600 \mathrm{ml}$ dan tiap kardus di isi dengan 15 botol yang berisi kertas merang untuk tiap varietas. Kardus ini merupakan ruangan tertutup untuk mengecambahkan benih kacang hijau (Wardani, 2014). Gas etilen yang dipakai untuk perlakuan dibuat dari karbid (kalsium karbida $=\mathrm{CaC} 22$ ) yang biasanya digunakan untuk proses pematangan buah, khususnya buah klimaterik. Bubuk karbid sebanyak $1 \mathrm{~g}$ dicampur dengan air sebanyak $100 \mathrm{ml}$ akan menghasilkan $349 \mathrm{ml}$ asetilen (Purnawan, 2010).

Penanaman kacang hijau dilakukan dengan metode Uji Kertas Digulung dan 
Diletakkan dalam posisi berdiri Dalam Plastik (UKDdp) dengan media kertas merang (Kartasapoerta, 1992). Dua lembar kertas merang yang sudah dibasahi dengan air secukupnya, dihamparkan di atas alas plastik. Kemudian 25 benih kacang hijau ditanam secara teratur di atas kertas merang. Setelah itu, diambil 1 lembar kertas merang yang sudah dibasahi untuk menutup dan selanjutnya digulung beserta alasnya, lalu diberi selotip dan kemudian diletakkan dalam posisi berdiri di dalam botolyang sudah diberi $10 \mathrm{ml}$ air (Wardani, 2014).

Dalam eksperimen ini 3 varietas kacang hijau yang sudah ditanam seperti yang diuraikan pada 3.4.2, diletakkan di dalam dua buah kardus secara bersamaan sebanyak 5 kali ulangan. Pada setiap kardus terdap 15 gulungan yang berisi masingmasing 25 butir kacang hijau. Pada kardus pertama tidak diperlakukan dengan karbid, sedangkan kardus kedua diperlakukan dengan gas karbid yang diberikan pada hari ke-2 perkecambahan.

\section{HASIL DAN PEMBAHASAN}

\section{Sebelum penelitian dilaksanakan, telah dilakukan pemilihan benih yang} berkualitas dari tiga varietas kacang hijau, benih yang tenggelam dalam air adalah benih yang baik dapat digunakan dalam penelitian. Kemudian dalam penelitian juga digunakan kalsium karbida yang menghasilkan gas etilen dengan konsentrasi yang lebih tinggi. Dalam penelitian digunakan dua perlakuan yaitu tanpa karbid (kontrol) hanya sebagai pembanding saja dan yang diberi karbid. Parameter-parameter yang diamati dalam penelitian ini mencakup panjang hipokotil kacang hijau, diameter hipokotil dan derajat bengkokan kacang hijau. Pada penelitian ini digunakan 3 varietas kacang hijau yaitu VIMA I, Seriti dan Kutilang yang di tumbuhkan sampai dengan fase perkecambahan. Yang mana bagian dari kecambah ketiga varietas kacang hijau tersebut terdiri dari beberapa bagian yaitu epikotil, hipokotil dan akar. Pada gambar 11 dapat dilihat rata-rata dari panjang kacang hijau dari 3 varietas yaitu varietas VIMA I adalah13,9 cm, Kutilang adalah 12,605 cm dan varietas yang memiliki panjang terendah adalah Seriti dengan 9,851 cm, sehingga terlihat perbedaan varietas kacang hijau yang diberi karbid. Hal ini pula dapat dibuktikan dengan hasil analisis varian (ANAVA) sederhana bahwa faktor perlakuan yaitu kacang hijau yang diberi karbid menyebabkan perbedaan pada panjang kacang hijau, dimana $\mathrm{F}$ hitung dari faktor perlakuan lebih besar dari Ftabel. Pada tanaman yang memperlihatkan triple response, pertumbuhan panjang kecambahnya sangat cepat namun terjadi pengerdilan pada bagian batang. Hal ini dapat diasumsikan dengan tidak adanya asupan oksigen yang maksimal serta pencahayaan yang kurang sehingga mengakibatkan tanaman cenderung memanjang untuk mencari asupan respirasi yang cukup. Hal ini berhubungan juga dengan bersintesisnya hormon etilen yang mana semakin besar konsentrasi etilen maka semakin cepat stimulasi respirasinya (Ningrum, 2013).

Hasil pengukuran diameter hipokotil kacang hijau sebenarnya tidak jauh berbeda nilainya. Berdasarkan grafik (gambar 12) maupun hasil ANAVA sederhana memiliki perbedaan diameter hipokotil kacang hijau yang diberi karbid. dimana $\mathrm{F}$ hitung dari faktor perlakuan lebih besar dari $F$ tabel. Hal ini disebabkan karena tekanan turgor pada sel epidermis menurun dimana keluarnya sebagian air dari sel yang menyebabkan adanya jarak antara dinding sel dan membran sehingga sebagian besar bentuk sel epidermis kacang hijau adalah memanjang (Salisbury dan Ross, 1992). Semakin besar nilai derajat bengkokan kacang hijau akan menunjukkan kacang hijau yang rentan terhadap etilen dan memunculkan kebiasaan untuk membuat bengkokan (hook) yang menyebabkan kacang hijau akan bertumbuh secara mendatar. Epikotil merupakan bagian dari batang kecambah yang membengkok karena etilen. Menurut penuturan ahli fisiologi yang berasal dari Rusia yaitu Dimitry N. Neljubow (1876-1926) bahwa bengkokan ini memungkinkan batang bertumbuh secara horizontal atau mendatar sehingga pertumbuhan tanaman akan menjadi tidak normal. Pada gambar 13 dapat dilihat bahwa pengaruh karbid dapat menyebabkan perbedaan pada derajat bengkokan pada ke 3 varietas kacang hijau dimana varietas kutilang memiliki nilai derajat tertinggi dengan $120.85^{\circ}$, varietas Seriti $119.95^{\circ}$ dan varietas kacang hijau yang memiliki nilai 
bengkokan terendah adalah VIMA I 86,7 . Jika dilihat dari parameter diatas dapat dilihat bahwa varietas VIMA I merupakan varietas yang baik, karena varietas ini tidak terpengaruh dengan pemberian karbid sehingga nilai derajat bengkokannya merupakan yang terendah di antara ke 3 varietas ini. Hal ini dapat di asumsikan dengan pertumbuhan kacang hijau yang batangnya tumbuh lurus dan derajat pembengkokan epikotilanya tidak terlalu membengkok.

Jaringan sel yang di amati adalah pada bagian irisan penampang melintang dari sel epidermis hipokotil kacang hijau. Jaringan epidermis adalah lapisan-lapisan sel yang berada paling luar pada bagian-bagian tumbuhan seperti akar, batang, daun, bunga, buah dan biji. Telah banyak dilakukan pengkajian yang membuktikan bahwa epidermis terdapat pada tumbuhan muda (kecambah), tumbuhan lunak (bayam), tummbuhan kayu (perdu dan pohon-pohon), yaitu di ujung ranting dan permukaan daun yang berfungsi melindungi jaringan bagian didalamnya (Sutriadi, 2009). Pada kecambah kacang hijau yang memperlihatkan triple respon yang direfleksikan dengan pertumbuhan batang terhambat dan batang yang sedikit menebal karena pemelaran sel ke arah samping (Salisbury dan Ross, 1995).

Pada hasil pengamatan irisan sel epidermis dari hipokotil kacang hijau tidak terlihat adanya perubahan bentuk sel yang besar pada ketiga varietas. Hal ini mungkin disebabkan karena belum terlalu berpengaruhnya konsentrasi etilen yang dihasilkan oleh karbid terhadap bentuk sel ketiga varietas kecambah kacang hijau, pembuatan irisan pada batang kacang hijau terlalu tebal karena batang kacang hijau yang terlalu kecil dan juga pada bagian sel epidermis kecambah kacang hijau terlalu banyak mengandung air, sehingga tidak dapat terlihat jelas bentuk sel kecambah kacang hijau. Sehingga hal ini perlu di evaluasi kembali dengan konsentrasi karbid yang memberikan pengaruh lebih besar terhadap bentuk sel epidermis kecambah kacang hijau.

\section{KESIMPULAN}

Dari hasil penelitian ini, diperoleh kesimpulan bahwa diantara ketiga varietas kacang hijau yang diuji, varietas VIMA I merupakan varietas yang tahan terhadap peningkatan etilen. Karena kecambah kacang hijau varietas VIMA 1 memperlihatkan tingkatan triple response yang rendah hal ini direfleksikan dengan tinggi kecambah dengan nilai tertinggi dan derajat bengkokan (hook) paling kecil.

\section{DAFTAR PUSTAKA}

Anwari, M., Soehandi, R., Iswanto, R, dan Sumartini. 2006. Pembentukan Varietas Unggul Kacang Hijau Tahan Penyakit Embun Tepung. Buletin Palawija. Malang.

Balikabi.2005. Teknologi Produksi Kacangkacangan dan Umbi-Umbian. Balai Peneletian Tanaman KacangKacangan dan Umbi-Umbian. Malang.

Buranatham, W.S., Kongsripun, and D. Shugamnert. 1992. Recent Advances in Multiple Cropping with Hevea in Southern Thailand. $7^{\text {th }}$ ANRPC Seminar.Hat Yai. Thailand.

Campbell, N.A ., J.B. Reece, Urry L.A., Cain M.L., Wasserman S.A., Minorsky P.V., dan Jackson R.B. 2012. Biologi Jilid 2- Edisi Kedelapan. Penerbit Erlangga, Jakarta.

Campbell, N.A., J.B Reece, dan L.G Mitchell. 2002. Biologi Edisi Kelima Jilid I. Penerbit Erlangga, Jakarta.

Djukri, B.S. dan Poerwoko. 2003. Pengaruh Naungan paranet terhadap sifat toleransi tanaman talas (Colocasiaesculenta $(\mathrm{L}) \quad$ Schott). Ilmu Pertanian 10 (2):17-25.

Fachruddin, L. 2000. Budidaya Kacangkacangan. Yogyakarta.

Guzman, P. dan J.R Ecker. 1990. Exploiting the Triple Response of Arabidopsis Ethylene-Related Mutants. American Society of Plant Physiologist, The Plant Cell. 23(2) : 513-514.

Harjadi, S.S. 2009. Zat Pengatur Tumbuhan. Penerbit Penebar Swadaya, Jakarta.

Intan, R, D, A. 2008. Peranan dan Fungsi fitohormon bagi pertumbuhan tanaman. Makalah. Fakultas Pertanian. Universitas Pajajaran.

Kartasapoerta, A.G. 1992. Teknologi Benih: Pengolahan Benih dan Tuntunan Praktikum. Rineka Cipta, Jakarta. 
Ketayama, K., L.U. de la Cruz, S. Sakurai, dan K. Osumi. 1998. Effect of shelter trees on growth and yield of pechai (Brassica chinensis L.), Mungbean (Vigna radiate L.) and Maize (Zea mays L. ). JARQ.32(2):139-144.

Koesmaryono Y, L Sabaruddin, dan K Stigter 2005. Dervated Argrometeorological information serving government and farmers decisions in some intercropping systems in Southeast Sulawesi, Indonesia. J. agric. Meteorol. 60:343347.

Madurita, 2004. Evaluasi Ketahanan 20 Genotip Kacang Hijau (Vigna Radiata (L) Wilzcek) Terhadap Penyakit bercak daun. Universitas Brawijaya Malang.

Mejaya, I.M.J., A. Kasno, dan M.M. Adie. 1989. Evaluasi hasil dan adaptasi genotype kacang hijau di lingkungan monokultur dant umpang sari dengan jagung. Penelitian Palawija. 4(2):135141.

Muafifah.2006. Karakteristik Morfologi dan Anatomi Beberapa Genotip dan Hubungannya dengan Hasil Kacang Hijau (Vigna Radiata (L) Wilczek). Skripsi Jurusuan Biologi. Malang : UIN Maulana Malik Ibrahim Malang.

Mustakim. M. 2015 .Budidaya Kacang Hijau Secara Intensif. Pustaka Baru Press.

Ningrum,D.A. 2013. Pengaruh Lama Waktu Pemeraman Pisang Raja Bulu (Musa paradisiacal L. VarSapientrum) menggunakan (Batu Karbid) terhadap kadar karbohidrat dan Vitamin C. IKIP PGRI, Semarang.

Nio, S.A., S.M. Tondais. dan R. Butarbutar. 2010. Evaluasi Indikator Toleransi Cekaman Kekeringan pada Fase Perkecambahan Padi (Oryza sativa L.). Jurnal Biologi. 14 (1): 50-51.

Purnawan, H. 2010. Pengertian Karbid. Universitas Gajah Mada. http://harispurnawan.web.ugm.ac.id/?pilih=news \&mod=yes \&aksi=lihat\&id=22. Diaksespadatanggal 24 April 2016.

Purwono, Purnamawati H. 2008. Budidaya 8 JenisTanamanPanganUnggul. Jakarta (ID): PenebarSwadaya.
Pusat Penelitian dan Pengembangan Tanaman Pangan. 2012. VIMA 1, VUB Kacang Hijau umur genjah, Masak Serempak, dan tahan penyakit embun tepung. Malang.

Raghavan, C., E.K. Ong, M.J. Dalling, T.W. Stevenson. 2006. Regulation of Genes Associated with Auxin, Ethylene and ABA Pathways by 2.4 dicholorophenoxyacetic acid in Arabidopsis. FuntIntegr Genomics. 6 (1):60-70.

Roman, G.B., Lubarsky, J.J Kieber, M. Rothenberg dan J.R. Ecker. 1995. Genetic Analyssis of Ethylene Signal Transduction in Arabidopsis Thaliana: Five Vove; Mutant Loci Integreted into a Stress Response Pathway. The Genetics Society of America:13941395.

Rukmana, R. 1997. Kacang Hijau Budidaya dan Pasca Panen. Kanisius. Jakarta.

Salisbury, F.B dan C.W. Ross. 1995. Fisilogi Tumbuhan Jilid 3 Edisi ke-empat (Terjemahan). ITB, Bandung.

Sangkkara, U.R. 1988. Mungbean as a component of annual mixed cropping system. pp.406-411. In. S. Shanmuga sundaram (ed.). Mungbean.Proc.Of the Second International Symposium. Bangkok, Thailand. 16-60 November 1987. AVRDC. Shanhua, Tainan.

Satriadi, M. 2009. Validasi Metode Uji Daya Berkecambah Benih Trembesi (Samanea Saman) Menggunakan Instruksi Kerja 08 Laboratorium Badan Perbenihan Tanaman Hutan Bali Nusa Tenggara.

Setyowati, T. dan Furqonita, D. 2007.Biologi Interaktif. Azka Press, Jakarta Timur.

Somaatmadja, S. 1993. Proses Sumber Daya Nabati Asia Tenggara I. Kacang Kacangan. Jakarta : PT Gramedia Pustaka Utama.

Sumiati, N. dan Sumiati, E. 2001. Pengaruh Vernalisasi, Giberelin dan Auxin terhadap Pembungaan dan Hasil Biji Bawang Merah. Jurnal Holtikultura. (11) $1: 1-8.41$.

Sunantara, I.M.M. 200. Teknik produksi benih kacang hijau. No. Agdex: 142/35. No.Seri: 03/Tanaman/2000/September 2000. Instalasi Peneletian dan Pengkajian Teknologi Pertanian Denpasar Bali. 
Ting, I. 1982 .Plant Physiology. Addison, Willey California.

Tjitrosoepomo, G. 1996. Taksonomi Tumbuhan (Spermatophyta). Yogyakarta: Gajah Mada Univerty Press.

Wardani, K.E. 2014.Kajian Ethylene Triple Response Terhadap Kecambah Tiga Varietas Kedelai [SKRIPSI]. FMIPA UNSRAT. Manado

Weaver, J.E., dan F.E. Clements. 1989. Plant Ecology. $2^{\text {nd }}$ Edition. Tata McGrawHill Publishing Company, Ltd. New Delhi.

Widyastuti, N. dan D. Tjokrokusumo.2007. Pernanan Beberapa Zat Pengatur Tumbuh (ZPT) Tanaman Pada Kultur in Vitro.JurnalSainsTeknologi Indonesia. 3(5):55-63.
Yamaguchi, M dan Rubatzky, V. E. 1998.SayuranDunia 2 Prinsip, Produksi dan Gizi edisi kedua, Bandung: ITB Bandung.

Yamanaka, M., Takahashi, R., Nakayama.M., Kanazawa. A. Jun. A. 2012 An Actiev CACTA-Family Transposable Element is Responsible for Flower Variegation in Wild Soybean Glycine soja. The Plant Genome (5):2. 